\title{
Uji Daya Hambat Ekstrak Etanol Kubis (Brassica oleracea var. capitata f. alba) Terhadap Bakteri Staphylococcus aureus Secara In Vitro
}

\author{
SITI FATIMAH ${ }^{1}$, FITRI NADIFAH ${ }^{1}$, ISLAMIATI BURHANUDIN ${ }^{1}$ \\ ${ }^{1}$ Program Studi D3 Analis Kesehatan STIKES Guna Bangsa Yogyakarta \\ J1. Ring Road Utara, Sleman, Daerah Istimewa Yogyakarta 55283 \\ email: fitri.nadifah@gmail.com
}

\begin{abstract}
Infectious diseases are diseases caused by pathogenic bacteria that enter the body, multiply and cause disease. One cause of the disease is a bacterial infection of Staphylococcus aureus. Treatment of infectious diseases is usually done by giving antibiotic but some types of bacteria become resistant. Utilization of plants as traditional medicine is growing rapidly and many alternative medicine used by some communities, one of which is cabbage (Brasicca oleracea var. capitata $f$. alba) containing antibacterial compounds such as flavonoids, saponins, polyphenols, tannins and sulfur. Such compounds capable of inhibiting the growth of bacteria by inhibiting bacterial cell wall synthesis, protein synthesis, and forming complex compounds against extracellular proteins that interfere with bacterial cell membrane integrity. This research is an experimental research with the aim to determine the inhibitory ethanol extract of cabbage (Brasicca oleracea var. capitata f. alba) against Staphylococcus aureus in in vitro. Antibacterial test method used is that pitting diffusion method. Ethanol extract of cabbage (Brasicca oleracea var. capitata f. alba) can inhibit the growth of Staphylococcus aureus on the mark with the formation of a clear zone around the wells which starts from a concentration of $20 \%$.
\end{abstract}

Keywords: cabbage (Brasicca oleracea var. capitata f.alba) extract, inhibition, Staphylococcus aureus

\section{INTISARI}

Penyakit infeksi adalah penyakit yang disebabkan oleh bakteri patogen yang masuk ke dalam tubuh, berkembang biak dan menyebabkan penyakit. Salah satu bakteri yang sering menyebabkan infeksi adalah bakteri Staphylococcus aureus. Pengobatan penyakit infeksi biasanya dilakukan dengan memberi antibiotik namun beberapa jenis bakteri menjadi resisten. Pemanfaatan tanaman sebagai obat tradisional berkembang pesat dan banyak obat alternatif yang digunakan oleh beberapa masyarakat, salah satunya adalah kubis (Brasicca oleracea var. capitata f. alba) yang mengandung senyawa antibakteri seperti flavonoid, saponin, polifenol, tanin dan belerang. Senyawa tersebut mampu menghambat pertumbuhan bakteri dengan menghambat sintesis dinding sel bakteri, sintesis protein, dan pembentukan senyawa kompleks melawan protein ekstraselular yang mengganggu integritas membran sel bakteri. Penelitian ini merupakan penelitian eksperimental dengan tujuan mengetahui daya hambat ekstrak etanol kubis (Brasicca oleracea var. capitata f. alba) terhadap Staphylococcus aureus secara in vitro. Metode uji antibakteri yang digunakan adalah metode difusi sumuran agar. Ekstrak etanol kubis dapat menghambat pertumbuhan Staphylococcus aureus pada tanda dengan pembentukan zona bening di sekitar sumur yang dimulai dari konsentrasi $20 \%$.

Kata Kunci: daya hambat, ekstrak etanol kubis (Brasicca oleracea var. capitata $f$. alba), Staphylococcus aureus

\section{PENDAHULUAN}

Penyakit infeksi adalah jenis penyakit yang disebabkan oleh bakteri patogen yang masuk ke dalam tubuh, berkembang biak dan menimbulkan penyakit. Penyakit infeksi biasanya banyak terdapat di daerah tropis seperti Indonesia, bahkan ada yang bersifat endemik menetap berada dalam masyarakat 
pada suatu tempat atau populasi tertentu. Salah satu bakteri yang sering menyebabkan infeksi adalah bakteri Staphylococcus aureus. Staphylococcus aureus dapat menyebabkan terjadinya berbagai jenis infeksi mulai dari infeksi kulit ringan, keracunan makanan sampai dengan infeksi sistemik. Infeksi kulit yang biasanya disebabkan oleh Staphylococcus aureus yaitu impetigo, selulitis, folikulitis, dan abses. Staphylococcus aureus juga sering menyebabkan keracunan makanan karena adanya enterotoksin yang dihasilkan oleh Staphylococcus aureus yang terdapat pada makanan yang tercemar (Refdanita dkk., 2004).

Bakteri Staphylococcus aureus juga dapat menyebabkan infeksi nosokomial. Staphylococcus aureus merupakan bakteri pemeran utama yang menyebabkan terjadinya infeksi nosokomial yaitu sebesar $34 \%$. Pengobatan penyakit infeksi oleh bakteri Staphylococcus aureus tersebut biasanya dilakukan dengan pemberian antibiotik yang dapat menghambat atau membunuh bakteri. Antibiotik yang sering digunakan adalah tetrasiklin. Tetrasiklin merupakan antibiotik yang dapat mengganggu proses sintesis protein dan merupakan antibiotik pilihan yang mampu menghambat bakteri gram positif maupun gram negatif. Golongan Staphylococcus memiliki enzim betalaktamase yang dapat memecah cincin betalaktam pada antibiotik tersebut dan membuatnya menjadi tidak aktif (Junaidin dan Admin, 2007).

Dampak buruk penggunaan obat yang tidak rasional dan penggunaan antibiotik yang berlebihan yaitu menyebabkan perubahan ekologi kuman dan menimbulkan resistensi kuman (Sadikin, 2011). Dewasa ini perkembangan pengobatan telah mengarah kembali ke alam (back to nature) karena obat tradisional telah terbukti lebih aman dan tidak menimbulkan efek samping seperti halnya obat-obat kimia. Pemanfaatan tumbuhtumbuhan sebagai obat tradisional berkembang pesat dan banyak dijadikan obat alternatif oleh sebagian masyarakat. Obat tradisional merupakan bahan atau ramuan yang berupa bahan tumbuhan, bahan hewan, bahan mineral, atau sediaan sarian yang secara turun temurun telah digunakan untuk pengobatan berdasarkan pengalaman (Tjay dan Raharjda, 2007).

Setiap tanaman memproduksi senyawa kimia yang mempunyai fungsi sendiri-sendiri, seperti kubis (Brassica oleracea var. capitata $f$. alba) yang mempunyai kandungan senyawa flavonoid, saponin, polifenol, sulfur, dan tanin. Senyawa tanin mampu menghambat sintesis dinding sel bakteri dan sintesis protein sel bakteri. Flavonoid berfungsi sebagai antibakteri yang membentuk senyawa kompleks terhadap protein extraseluler yang mengganggu integritas membran sel bakteri dan berfungsi sebagai zat anti inflamasi, anti oksidan, analgesik dan antibakteri (Manoi dan Balittro, 2009). Penelitian ini bertujuan untuk mengetahui ekstrak etanol kubis (Brassica oleracea var. capitata $f$. alba) mempunyai kemampuan untuk menghambat pertumbuhan bakteri Staphylococcus aureus. Penelitian ini diharapkan dapat dijadikan sebagai solusi peningkatan kasus resistensi bakteri dan sebagai pengobatan alternatif penyakit infeksi kulit dan keracunan makanan yang disebabkan oleh bakteri Staphylococcus aureus.

\section{METODE}

Kubis (Brassica oleracea var. capitata $f$. alba) yang digunakan adalah kubis yang putih, segar dan tidak cacat yang diperoleh di daerah Banyuroto, Magelang, Jawa Tengah.

Pembuatan ekstrak kubis metode maserasi. Kubis (Brassica oleracea var. capitata f. alba) dipisahkan dari kropnya dan dikeringkan pada suhu $45^{\circ} \mathrm{C}$ menggunakan oven sampai kadar airnya kurang dari $10 \%$. Kubis (Brassica oleracea var. capitata $f$. alba) yang telah kering dihaluskan menggunakan mesin penyerbuk dengan lubang saringan $1 \mathrm{~mm}$. Serbuk kubis yang telah halus dimasukkan dalam maserator dan direndam dengan etanol 50\% lalu diaduk selama 15 menit. Larutan ekstrak didiamkan selama 3x24 jam, ekstraksi di ulang sebanyak 3 kali. Larutan ekstrak di saring menggunakan kertas saring. Filtrat yang diperoleh 
dipekatkan dalam rotary evaporator pada suhu $<50^{\circ} \mathrm{C}$ sampai kental. Ekstrak etanol kubis dalam sediaan pasta dibuat menjadi konsentrasi $100 \% \mathrm{~b} / \mathrm{v}$ yang diencerkan dengan 5\% PEG 400 (poliethylen glicol). Ekstrak etanol kubis dalam konsentrasi $100 \% \mathrm{~b} / \mathrm{v}$ diencerkan menjadi konsentrasi $20 \% \mathrm{~b} / \mathrm{v}, 40 \%$ $b / v, 60 \% \mathrm{~b} / \mathrm{v}$ dan $80 \% \mathrm{~b} / \mathrm{v}$ yang dilakukan secara aseptik dengan volume yang sesuai.

Tahap pengujian. Biakan murni Staphylococcus aureus dicat gram terlebih dahulu dan dilihat di bawah mikroskop untuk memastikan koloni dari Staphylococcus aureus. Selanjutnya dari media Na diambil biakan murni Staphylococcus aureus menggunakan ose dan disuspensikan dengan $\mathrm{NaCl}$ fisiologis $0,85 \%$ sebanyak $5 \mathrm{ml}$ kemudian dihomogenkan sampai didapatkan kekeruhan yang setara dengan $10^{6} \mathrm{CFU} / \mathrm{ml}$ (Mc Farland1). Kapas lidi steril dicelupkan ke dalam suspensi bakteri lalu ditekan-tekan pada dinding tabung sehingga tidak terlalu basa dan dioleskan pada permukaan media Muller Hinton Agar hingga rata, selanjutnya pada setiap petri dibuat 1 lubang sumuran. Setiap lubang sumuran diberi $20 \mu$ l ekstrak etanol kubis (Brassica oleracea var. capitata f. alba) dengan berbagai konsentrasi dan dilakukan pengulangan sebanyak $3 \mathrm{x}$. Media diinkubasi pada suhu $37^{\circ} \mathrm{C}$ selama 24 jam. Bahan yang digunakan sebagai kontrol yaitu PEG 5\% dan tetrasiklin. Pembacaan hasil dilakukan dengan cara dengan mengukur zona jernih di sekitar sumuran menggunakan mistar. Pembacaan hasil berdasarkan pengamatan diameter zona jernih di sekitar sumuran media MHA kemudian di rata-rata diameternya.

\section{HASIL}

Dalam penelitian ini ekstrak etanol kubis (Brassica oleracea var. capitata $f$. alba) mampu menghambat pertumbuhan bakteri Staphylococcus aureus yang ditandai dengan terbentuknya zona jernih di sekitar sumuran. Zona jernih tersebut diukur dengan menggunakan penggaris dalam satuan milimeter. Kontrol negatif yang digunakan pada penelitian ini adalah Polyethilene glycol $5 \%$ yang berperan sebagai larutan pengencer ekstrak etanol kubis, sedangkan kontrol positif menggunakan Tetrasiklin.

Data hasil rata-rata diameter zona jernih ekstrak etanol kubis terhadap bakteri Staphylococcus aureus dapat dilihat pada tabel 1.

Tabel 1. Hasil pengukuran rata-rata diameter zona jernih ekstrak kubis (Brassica oleracea var. capitata $f$. alba) terhadap pertumbuhan bakteri Staphylococcus aureus.

\begin{tabular}{cccccc}
\hline \multirow{2}{*}{ No. } & \multirow{2}{*}{ Konsentrasi } & \multicolumn{3}{c}{ Zona Jenih (mm) } & \multirow{2}{*}{ Rata-Rata (mm) } \\
\cline { 3 - 5 } $\mathbf{1}$ & & $\mathrm{A}$ & $\mathrm{B}$ & $\mathrm{C}$ & \\
\hline $\mathbf{2}$ & $20 \%$ & 8 & 8 & 7 & 7,6 \\
\hline $\mathbf{3}$ & $40 \%$ & 11 & 11 & 13 & 11,6 \\
\hline $\mathbf{4}$ & $60 \%$ & 12 & 12 & 12 & 12 \\
\hline $\mathbf{5}$ & $80 \%$ & 12 & 14 & 13 & 13 \\
\hline $\mathbf{6}$ & $100 \%$ & 17 & 17 & 17 & 17 \\
\hline $\mathbf{7}$ & Tetrasiklin & 23 & - & - & 23 \\
\hline
\end{tabular}

Berdasarkan data pada tabel 1 di atas, hasil rata-rata terbesar diameter zona jernih ekstrak etanol kubis (Brassica oleracea var. capitata f. alba) terhadap bakteri Staphylococcus aureus pada konsentrasi $100 \%$ yaitu sebesar $17 \mathrm{~mm}$ sedangkan ratarata terkecil diameter zona jernih terdapat pada konsentrasi $20 \%$ yaitu sebesar 7,6 mm. Pada konsentrasi $80 \%$ didapatkan rata-rata diameter zona jernih yaitu sebesar $13 \mathrm{~mm}$, konsentrasi $60 \%$ sebesar $12 \mathrm{~mm}$ dan konsentrasi $40 \%$ yaitu sebesar $11,6 \mathrm{~mm}$. Hasil di atas menunjukkan bahwa ekstrak etanol kubis mampu menghambat pertumbuhan bakteri Staphylococcus aureus yang diikuti dengan semakin besarnya konsentrasi ekstrak etanol kubis maka semakin besar pula zona jernih yang terbentuk di sekitar sumuran. 


\section{PEMBAHASAN}

Metode ekstraksi yang digunakan pada penelitian ini adalah metode maserasi yaitu proses pengekstrakan simplisia menggunakan pelarut dengan beberapa kali pengocokan atau pengadukan pada temperatur ruang. Penelitian ini dilakukan untuk mengetahui daya hambat ekstrak etanol kubis (Brassica oleracea var. capitata $f$. alba) dalam menghambat pertumbuhan bakteri Staphylococcus aureus secara in vitro. Metode yang digunakan yaitu metode difusi sumuran agar, metode ini cocok untuk menguji bahan yang berupa cairan. Metode difusi merupakan metode umum yang praktis, cepat dalam pembacaan hasil mudah dan murah, sehingga cocok untuk digunakan dalam penelitian, walaupun pada metode difusi tersebut kadar bunuh minimal tidak dapat ditentukan (Faatih, 2005). Media Muller Hinton digunakan sebagai media pertumbuhan bakteri Staphylococcus aureus, karena media ini telah direkomendasikan oleh WHO untuk uji antibakteri terutama bakteri aerob dan facultative anaerobic bacteria seperti Staphylococcus aureus. Media agar ini juga telah terbukti memberikan hasil yang baik dan reproduksibel. Media agar ini mengandung sulfonamida, trimethoprim, dan inhibitor tetrasiklin yang rendah serta memberikan pertumbuhan bakteri yang memuaskan (WHO, 2011).

Penanaman suspensi bakteri

Staphylococcus aureus pada media Muller Hinton Agar menggunakan kapas lidi steril. Dalam penanaman suspensi bakteri harus diperhatikan dengan baik karena akan berpengaruh pada hasil penelitian. Jika pengambilan suspensi bakteri yang terlalu banyak atau pertumbuhan bakteri pada media yang terlalu tebal maka akan menyebabkan diameter zona jernih yang terbentuk kecil, sehingga pada prosedur kerja penanaman dijelaskan setelah kapas lidi steril dimasukkan ke dalam suspensi bakteri, kapas lidi steril ditekan di dinding tabung terlebih dahulu untuk mengurangi jumlah bakteri agar pertumbuhan bakterinya merata.

Senyawa aktif yang terkandung dalam ekstrak etanol kubis (Brassica oleracea var. capitata $f$. alba) memiliki beragam efek biologis dan farmakologi, antara lain: flavonoid, saponin, polifenol, sulfur dan tanin. Senyawa-senyawa tersebut mempunyai fungsi tersendiri dalam menghambat pertumbuhan bakteri Staphylococcus aureus. Senyawa tanin mampu menghambat sintesis dinding sel bakteri, sintesis protein sel bakteri dan senyawa flavonoid akan membentuk senyawa kompleks terhadap protein ekstraseluler yang mengganggu integritas membran sel bakteri (Manoi dan Balittro, 2009). Senyawa-senyawa tersebut terbukti dapat menghambat pertumbuhan bakteri Staphylococcus aureus yang dilihat dari terbentuknya zona jernih di sekitar sumuran.

Penelitian ini dilakukan dengan pengulangan yaitu sebanyak tiga kali dengan menggunakan 5 konsentrasi, yaitu $20 \%, 40 \%$, $60 \%, 80 \%$ dan 100\%. Berdasarkan hasil penelitian yang telah dilakukan, menunjukkan bahwa ekstrak etanol kubis (Brassica oleracea var. capitata $f$. alba) dapat menghambat pertumbuhan bakteri Staphylococcus aureus yang ditandai dengan terbentuknya zona jernih di sekitar sumuran. Zona jernih ekstrak etanol kubis terhadap bakteri Staphylococcus aureus mengalami peningkatan dari konsentrasi 20\% sampai $100 \%$. Pengaruh tersebut dapat dilihat dari semakin tinggi konsentrasi maka semakin besar zona jernih yang terbentuk karena antibakteri yang terkandung dalam ekstrak etanol kubis semakin besar.

Bakteri Staphylococcus aureus sensitif terhadap tetrasiklin, hal tersebut dilihat dari zona jernih yang terbentuk yaitu sebesar 23 mm. Zona jernih yang terbentuk menunjukkan bahwa bakteri Staphylococcus aureus sensitif terhadap tetrasiklin berdasarkan dengan ketentuan Soemarno (2000). Bakteri Staphylococcus aureus dikatakan resisten terhadap antibiotik jika zona jernih yang terbentuk kurang dari 14 $\mathrm{mm}$, intermediat $15-18 \mathrm{~mm}$ dan dikatakan sensitif (susceptible) jika lebih dari $19 \mathrm{~mm}$ (Soemarno, 2000). Ekstrak etanol kubis mempunyai kemampuan dalam menghambat pertumbuhan bakteri Staphylococcus aureus, hanya saja sensitivitas tetrasiklin lebih baik. Namun kubis bisa dijadikan sebagai 
pengobatan alternatif dalam menggunakan tanaman herbal untuk mengobati penyakit infeksi yang disebabkan oleh Staphylococcus aureus.

Pada penelitian ini digunakan Poliethylene glycol (PEG) 5\% sebagai pengencer ekstrak etanol kubis (Brassica oleracea var. capitata $f$. alba) karena sifatnya yang polar dan tingkat kelarutannya tinggi sehingga ketika direaksikan dengan ekstrak etanol kubis akan larut dengan sempurna. Poliethylene glycol digunakan sebagai kontrol negatif dengan tujuan untuk menguji apakah Poliethylene glycol memiliki senyawa yang dapat berpengaruh terhadap hasil penelitian. Kontrol positif yang digunakan pada penelitian ini adalah tetrasiklin karena bakteri Staphylococcus aureus sensitif terhadap antibiotik tersebut.

Hasil yang diperoleh dari uji kontrol negatif bahwa Poliethylen glicol (PEG) 5\% tersebut benar-benar tidak mengandung senyawa yang dapat berpengaruh terhadap pertumbuhan Staphylococcus aureus. Hal tersebut dapat mendukung hasil penelitian dan meyakinkan bahwa adanya hambatan terhadap pertumbuhan bakteri Staphylococcus aureus tersebut murni dari senyawa antibakteri yang dihasilkan oleh ekstrak etanol kubis (Brassica oleracea var. capitata f. alba).

\section{KESIMPULAN}

Ekstrak etanol kubis (Brassica oleracea var. capitata $f$. alba) dapat menghambat pertumbuhan bakteri Staphylococcus aureus secara in vitro pada konsentrasi $20 \%$. Perlu dilakukan penelitian lebih lanjut tentang daya hambat ekstrak etanol daun kubis terhadap bakteri gram positif dengan konsentrasi minimum 5\% untuk mengetahui batas daya hambatnya.

\section{DAFTAR PUSTAKA}

Faatih M. 2005. Aktivitas Anti-Mikrobia Kokon Attacus atlas L. Jurnal Penelitian Sains \& Teknologi. vol. 6(1): 35-48.

Junaidin dan Admin. 2007. Tanaman Katuk Gampang Ditanam. http://www.langitlangit.com. Yogyakarta: Agromedia Pustaka. diakses pada Desember 2016.

Manoi F dan Balittro. 2009. Binahong (Anredera cordifolia) Sebagai Obat. Bogor: Pusat Penelitian dan Pengembangan Perkebunan.

Refdanita, Maksum, Nurgani, dan Endang. 2004. Pola Kepekaan Kuman Terhadap Antibiotika di Ruang Rawat Intensif Rumah Sakit Fatmawati Jakarta Tahun 2001-2002. Jurnal Kesehatan. vol. 8(2): 41-48.

Sadikin Z. 2011. Penggunaan Obat Rasional, Depertemen Farmakologi Fakultas Kedokteran Universitas Indonesia. Jurnal Indon Med assoc. vol. 61(4): 1-5.

Soemarno. 2000. Isolasi dan Identifikasi Bakteri Klinik. Yogyakarta: Akademi Analis Kesehatan Republik Indonesia. hal. 120.

Tjay TH dan Raharjda K. 2007. Obat-Obat Penting. Edisi 6. Jakarta: PT. Elex Komputindo. hal. 103-104.

Yuwono. 2010. Pandemi Resistensi Antimikroba: Belajar dari MRSA. J. of Kulit Kelamin. vol 42(1): 2837-2850. 